\title{
Biotechnology and the Development of Food Markets: Retrospect and Prospects
}

\author{
GianCarlo Moschini \\ Working Paper 08-WP 477 \\ August 2008 \\ Center for Agricultural and Rural Development \\ lowa State University \\ Ames, lowa 50011-1070 \\ www.card.iastate.edu
}

GianCarlo Moschini is a professor of economics and the Pioneer Hi-Bred International Chair in Science and Technology Policy at lowa State University.

This paper was prepared for presentation at the XIIth Congress of the European Association of Agricultural Economists (EAAE) in Ghent, Belgium, August 29, 2008.

The author thanks Brian Wright for helpful comments on an earlier version of the manuscript, Jim Register and Bronwyn Frame for valuable conversations on the science of agricultural biotechnology, and three EAAE readers for useful remarks.

This paper is available online on the CARD Web site: www.card.iastate.edu. Permission is granted to excerpt or quote this information with appropriate attribution to the authors.

Questions or comments about the contents of this paper should be directed to GianCarlo Moschini, 583 Heady Hall, lowa State University, Ames, IA 50011-1070; Ph: (515) 294-5761;

Fax: (515) 294-6336; E-mail: moschini@iastate.edu.

Iowa State University does not discriminate on the basis of race, color, age, religion, national origin, sexual orientation, gender identity, sex, marital status, disability, or status as a U.S. veteran. Inquiries can be directed to the Director of Equal Opportunity and Diversity, 3680 Beardshear Hall, (515) 294-7612. 


\begin{abstract}
Biotechnology has had an important impact on the agricultural and food industries over the last twelve years by way of fast and extensive adoption of a few genetically modified (GM) crops. This has produced large efficiency gains, including higher yields and reduced costs of weed and pest control, as well as some environmental benefits. The expected development of crops with additional agronomic traits, and with output traits to improve the nutrition and health attributes of food products, holds the potential for even more pervasive impacts. Full realisation of such promises may require overcoming the constraining effects of restrictive GM product regulations.
\end{abstract}

Keywords: biotechnology, genetically modified products, innovation, regulation, research and development.

JEL classification: Q16, Q18, O33, L51. 


\section{Introduction}

Concerns about food procurement have always mattered. The challenge of population pressure faced by an environment saturated with hunter-gatherers, catalysed by the changing climatic conditions at the end of the last Ice Age, led some people to attempt the cultivation of wild cereals in an effort to supplement their traditional sources of food (Cohen, 1977). Thus was agriculture born about twelve thousand years ago in the Fertile Crescent, and independently in at least five other distant locations over the next few millennia (Bellwood, 2005). A dwindling supply of large mammalian prey increased the attractiveness of early farming activities, and the ensuing Neolithic revolution saw the widespread transition of prehistoric humans from nomadic hunting-gathering bands to agriculture-based communities relying on a few successful domesticated species of plants and animals. Farming encouraged more permanent settlements, allowing the development of increasingly complex social structures and the ushering in of earlier civilisations.

The path from these early days to the modern world eventually saw the gradual augmentation of technology in food production, which supported a population expansion that is continuing to this day. Some see that as a vicious circle and also lament that ' $\ldots$ the transition from hunting and gathering to farming eventually resulted in more work, lower adult stature, worse nutritional condition and heavier disease burdens' (Diamond, 2002: 700). But civilisation has also led to knowledge accumulation, culminating in the industrial revolution and the opening up of increasingly new opportunities. The process of selection of plant and animal breeds practised by farmers since the early days of agriculture became more systematic with the discovery of Mendel's laws. The genetic improvement of domesticated plants and animals, coupled with the introduction and massive usage of chemical inputs, yielded impressive productivity gains that, along with mechanisation, transformed developed countries' agriculture in the twentieth century (see, for example, Gardner, 2002) and led to the so-called green revolution in many developing countries (Evenson and Gollin, 2003).

Biotechnology is the most recent manifestation of how new knowledge can be brought to bear on humanity's longstanding problem of food procurement. The term 'biotechnology' here refers to processes and products inherently related to the use of recombinant DNA techniques that originated in the 1970s, what some call 'modern biotechnology' (Zika et al., 2007). The ensuing ability to manipulate directly the genetic makeup of living organisms and its expression brought about a knowledge revolution in 
biology and opened up tantalising research opportunities, from basic science to practical applications in many fields. Health care problems provided the initial motivation for biotechnology and some early success stories (such as the commercial introduction of human insulin produced by genetically modified [GM] bacteria in 1982), and medical and biopharmaceutical applications are to this day attracting the largest share of biotechnology research and development $(\mathrm{R} \& \mathrm{D})$ resources. But many other applications of biotechnology have emerged, including its use at various stages in the agricultural and food industry.

In this article I review some aspects and implications of biotechnology product adoption in the agro-food sector. ${ }^{1}$ The predominant current manifestation of biotechnology in the agro-food sector is represented by GM or transgenic crops. In 2007, more than 114 million hectares worldwide were planted with GM varieties. The current contribution of GM crops to food supplies, and the potential future expansion of both the extent and the scope of biotechnology in agriculture, indeed makes it a 'global trend' worthy of consideration. But the development of biotechnology and the adoption of GM crops are still facing a number of obstacles and unresolved issues. Vigorous opposition by some segments of the public has plagued the reception of this technology from the start. Concurrently, we have seen a perhaps unprecedented regulatory activism, and the complex environment that is emerging is replete with obstacles for current and future GM innovations. This is particularly true for Europe. The EU has articulated an ambitious 'strategy for Europe' that, in the agro-food area, sees biotechnology as key 'in fighting hunger and malnutrition and feeding an increasing human population on the currently cultivated land area, with reduced environmental impact' (European Commission, 2002: 11). Yet the EU has positioned itself at one extreme of GM product regulations, developing and implementing restrictive policies that undoubtedly constrain the current status and the future potential of biotechnology in Europe.

\section{Biotechnology and the agro-food sector}

Applications to the agro-food sector represent a small part of modern biotechnology. Even within the narrow sectoral focus on agriculture and food, however, the scope of

\footnotetext{
${ }^{1}$ Given the exceedingly broad scope of the matter at hand, I do not attempt a systematic survey. My reference to the literature, while striving to be objective, is by necessity selective and unfortunately leaves out many relevant contributions.
} 
biotechnology is rather broad (Herdt, 2006). GM crops represent the largest segment at present. Current (first-generation) GM crops mostly embed agronomic traits such as herbicide resistance and insect resistance. Prospective applications include the tackling of more complex agronomic traits, such as drought resistance, as well as the expression of output traits. The latter include second-generation GM crops engineered to possess desirable quality attributes (such as improved nutritional profiles leading to functional food) and thirdgeneration GM crops that are suitable for novel uses (such as plant-made pharmaceuticals and plant-made industrial products). Animal applications are also being pursued and include the development of transgenic livestock and fish with various purposes, such as improved production traits, the building of genetic disease models, and the production of biomedically useful products in the animals' blood or milk (Wheeler, 2007).

\subsection{Current GM crops}

The pioneering efforts of a few companies_-with Monsanto showing a remarkable early commitment—led to crop varieties embedding traits engineered by recombinant DNA methods to be commercialised in $1996 .^{2}$ From early on, the strategy was to target traits that would have high value for the immediate end users (farmers) by pursuing products with herbicide resistance (HR) and/or insect resistance attributes. Weed and insect pressure have a first-order effect on expected yields, and their control by way of selective herbicides and pesticides is very costly. Earlier instances of first-generation GM crops attacked the problem by the insertion of a single foreign gene into the DNA of the desired crop. For example, Roundup Ready soybean is resistant to post-emergence exposure to the broad-spectrum herbicide glyphosate. This resistance was engineered by the insertion of a gene isolated from an Agrobacterium strain. Similarly, genes from the soil-dwelling bacterium Bacillus thuringiensis were inserted into corn and cotton to induce expression of proteins that are toxic to the larvae of certain Lepidopteran insects (such as the European corn borer in maize). ${ }^{3}$

Much work with GM crop breeding at present continues to target important agronomic traits. Relief from biotic stresses is provided by biotech traits that seek to provide

\footnotetext{
${ }^{2}$ For an engaging account of the road to initial commercialisation, see Charles (2002). For more details on the material of this section, see Zika et al. (2007) and references therein.

3 Because insect-resistant GM crops have been engineered so far with genes from Bacillus thuringiensis, such crops are hereafter referred to as Bt crops.
} 
insect resistance and herbicide resistance. For maize, in addition to resistance to the European corn borer noted earlier, a number of Bt varieties that are resistant to the corn rootworm (a Coleopteran insect) and a few related insects are currently available. Similarly, in cotton a number of traits aim at improved resistance to insects of the so-called budwormbollworm complex. A major trend for these main crops is the stacking of GM traits in the same plant. Three-trait stacks are now common, and more ambitious ones are on the way. ${ }^{4}$ In addition to combining herbicide and insect resistance, these stacks intend to build redundancies in GM crop resistance attributes that, among other things, should make the emergence of resistant weeds and insects (through the natural process of pest adaptation) less likely. Other agronomic traits currently under development include tolerance to abiotic stresses, in particular the development of drought-resistant varieties.

\subsection{Prospective GM crop applications}

Major crops for which adoption of GM traits is lagging are wheat and rice. Herbicideresistant wheat was on its way to commercialisation, but its development was halted by Monsanto in 2004 following pressure from the Canadian and US wheat industry (concerned about customer rejection in export markets). GM wheat resistant to fungal diseases (such as Fusarium) is being actively researched. GM rice varieties resistant to herbicides, abiotic stress and/or embedding Bt genes for insect resistance are being developed in the United States and China, as well as at the International Rice Research Institute, and commercialisation is expected in the near future. Unlike maize and soybean, the products of which are typically fed to animals or find their way into food as refined products, wheat and rice are staple foods, which, in view of the concerns discussed later, may account for a greater regulatory caution and a slower marketing timetable.

The development of desired traits in GM crops is not limited to the identification and insertion of foreign naturally occurring genes. The DNA of interest may be obtained from plants of the same species or from closely related plants, leading to cisgenic plants. An interesting alternative approach is the in vitro directed evolution of a gene of interest, obtained using the gene shuffling technique, which produces a 'synthetic' gene with an

\footnotetext{
${ }^{4}$ For example, Monsanto and Dow Agrosciences announced in September 2007 an agreement to develop an eight-gene stack for corn varieties, combining resistance to at least two herbicides and to a large spectrum of insects.
} 
amplified expression of the characteristic of interest. One such example is Dupont's 'GAT' technology conferring herbicide resistance in a novel way (glyphosate is actually detoxified in the plant). ${ }^{5}$ Another biotechnology technique that is becoming pivotal in crop improvement is marker-assisted breeding, whereby molecular biology techniques complement traditional breeding to accelerate the identification and selection of desired traits.

Future GM traits are expected to address output characteristics by improving the nutritional profile of the crop. 'Functional foods' with health benefits beyond basic nutrition present exciting possibilities for GM crop development (Pew Initiative, 2007). Examples are vegetable oils with an improved fatty acid profile, and staple crops with improved content of protein, minerals and vitamins. Such GM crops hold considerable potential for biofortification as a strategy to improve the nutrition of the poor in developing countries (Golden Rice, which embeds genes that improve the content of beta-carotene, the precursor of vitamin A, is a well-known example). Other crop biofortification projects include GM potato with higher protein content, as well as GM cassava and GM sorghum with a wide array of improved nutritional characteristics (Pray et al., 2007). Other future applications concern molecular farming whereby GM crops can be used to produce plant-made pharmaceuticals (e.g., monoclonal antibodies and vaccines) and plant-made industrial products (Moschini, 2006). Of current interest is the prospect of developing GM crops specifically designed for biomass yield for use in biofuel production.

\subsection{Concerns about GM crops}

Surveys of public attitudes routinely find that a sizeable segment of the population holds misgivings and reservations about biotechnology, and that this is particularly the case for agricultural and food applications of biotechnology (e.g., Gaskell et al., 2006). A variety of concerns to explain such an opposition to GM crops have been articulated, including (a) fear that intake of GM-based food products may be harmful to humans (e.g., the introduction of novel allergens), (b) concern that production of GM crops may be harmful for the environment (through gene flow, resistance build-up and biodiversity impacts), (c) ethical considerations, possibly predicated on religious views, and, (d) the role of patents and the proprietary interests of multinational corporations.

\footnotetext{
${ }^{5}$ Soybean and maize varieties with the GAT gene are expected to be marketed as early as 2009 .
} 
The intellectual root of safety concerns about GM crops can be traced back to the reservations and debate that greeted recombinant DNA technology immediately after its introduction, leading to a temporary voluntary moratorium on its use, the celebrated 1975 Asilomar conference, and subsequent guidelines and regulations by the US National Institutes of Health. Twenty years later-and, interestingly, on the eve of the release of commercial GM crops-all of the earlier serious concerns appeared to have been dispelled, at least to the satisfaction of scientists (Berg and Singer, 1995). In short, the evidence showed that millions of experiments had been carried out without incidents or documented hazards to public health. The paradigm-changing advent of recombinant DNA research had delivered much in terms of increasing knowledge of fundamental life processes, had already led to some useful products (for example, human insulin), and promised much for the future.

That this upbeat take-home message has been less than universally accepted in the GM food debate that followed certainly reflects, among other things, the difficulties of a rational public discourse on matters of sophisticated science that involve actors with vastly heterogeneous scientific literacy. Still, it is obviously impossible to claim the absence of any risk in this context. That biotechnology innovations may entail risks is thus possible, as one should expect with other technologies that are novel in some fundamental way, and for which some degree of uncertainty is inevitable. Some of these earlier apprehensions with GM crops were certainly legitimate. But, as with most such concerns, what is needed is more scientific knowledge (rather than an ideological reckoning).

A strong scientific consensus is emerging that GM technology itself poses no inherent risk for human health. The International Council for Science provided a careful, comprehensive assessment of this matter and concluded that 'there is no evidence of any ill effects from the consumption of foods containing genetically modified ingredients' (ICSU, 2003: 8). The conclusion that current GM products are as safe to eat as their conventional counterparts is the official opinion of a number of national science academies and the official position of several intergovernmental agencies, including the Codex Alimentarius Commission on food safety (a joint undertaking of the Food and Agriculture Organisation and the World Health Organisation). Indeed, some clearly positive effects are evident as well. For example, Bt maize shows reduced incidence of some mycotoxins (such as fumonisin) that may cause serious health problems in animals and humans. 
As for the environmental effects of GM crops, it is important to stress that the practice of agriculture inevitably affects the environment. That has been true since the early days, and it is certainly the case for the modern agricultural practices (with or without GM crops). In any event, a careful assessment of the vast scientific evidence accumulated over the last decade from field research and commercial cultivation has uncovered no evidence that GM crops have caused significant environmental harm. In fact, a number of positive environmental effects have been documented (e.g., Sanvido et al., 2006). Bt crops, particularly cotton, have led to a decrease in pesticide used for insect control, and adoption of HR crops has resulted in a favourable change in the composition of applied herbicides towards glyphosate, a herbicide that is considerably more benign (lower toxicity and lower persistence) than alternative, more selective herbicides that the GM crop practice replaces. Evidence from cotton cultivation in China, and from GM rice preproduction trials, has also shown another highly valuable impact from the induced reduction in the use of certain insecticides, namely, improved farmers' health (Huang et al., 2005). Cultivation of HR crops can also promote the use of reduced tillage practices, thereby reducing soil erosion.

\section{Adoption and economic impacts of current GM crops}

The GM crop technology has been extremely successful, by the historical standards of previous agricultural innovations. Only twelve years after their introduction, in 2007 GM crop varieties accounted for more than 114 million hectares worldwide (Table 1). Production is, however, highly concentrated: just three countries (Unites States, Brazil and Argentina) accounted for about 80 per cent of that area in 2007. Commercialised GM traits are also limited to a few main commodities. In 2007, virtually the entire GM area was taken by four crops with the following shares: soybean, 51.3 per cent; maize, 30.8 per cent; cotton, 13.1 per cent; and canola, 4.8 per cent. For countries that have led the adoption of GM crops, the market penetration (relative to traditional varieties) is remarkable. For example, in the United States, the country with the largest adoption to date, the share of land allocated to GM varieties in 2007 was 91 per cent for soybean, 73 per cent for maize and 87 per cent for cotton (NASS, 2007). From Table 1 it is evident that Europe is essentially absent from this picture; in 2007, only an estimated 110 thousand hectares of GM crops were grown in the EU_-involving just one event (MON810) in just one crop (maize) grown mostly in one country (Spain) (GM varieties accounted for about 1 per cent of the EU maize planted area). 
From an economic perspective, the first generation of GM crops increase expected yields and/or reduce the cost of weed and pest control (including cost savings made possible by the induced simplification of some crop management activities), as well as reducing the quantity of insecticides used to control insect populations (Fernandez-Cornejo and Caswell, 2006). The revealed preference of enthusiastic farmers' adoption choices, despite the price premium that GM varieties typically command, clearly attests to such efficiency gains. The yield gains due to Bt varieties, particularly in cotton, have been impressive, especially in developing countries (Qaim and Zilberman, 2003). Thus, GM crops enhance production efficiency, very much as did traditional agricultural research whose innovative products transformed twentieth century agriculture. In addition, as noted earlier, the reduced use of pesticides and the change in the composition of herbicide used brought about by GM crops translate into substantial positive environmental benefits.

One feature that distinguishes GM crops is that their development and commercialisation firmly belonged in the private sector, ${ }^{6}$ whereas earlier agricultural productivity gains owed much to public sector research (Huffman and Evenson, 1993). For crop breeders, the solution of the classical problem of how firms can profit from technological innovation (Teece, 1986) benefited from a changing landscape for intellectual property rights (IPRs). In the United States, the strengthening of IPRs that followed the 1982 establishment of a centralised appellate court for all patent cases was, for biotechnology innovations, compounded with the effects of the landmark 1980 Supreme Court decision of Diamond $v$. Chakerakarty that greatly expanded the scope of patenting in the life sciences. The recent strengthening of IPRs is a trend observed internationally as well, although important differences for the protection of agriculture-related innovations remain (Moschini, 2004).

The early enthusiasm for the life sciences company model has waned somewhat, but the burst of acquisitions, spin-offs and mergers that followed completely redesigned the seed and agro-chemical industries of developed countries, with an increased consolidation and a central role for intellectual property over both GM traits and germplasm (Wright and Pardey,

\footnotetext{
${ }^{6}$ A notable exception is GM papaya resistant to the ringspot virus, developed thanks to the efforts of researchers at Cornell University and at the University of Hawaii at Manoa. Papaya ringspot virus had nearly destroyed papaya production in Hawaii by the time GM varieties of papaya became commercially available in 1998, literally saving the industry.
} 
2006). ${ }^{7}$ The concentration of the seed and agro-chemical industries and the critical role of proprietary technologies are a common source of concern (see, for example, UNCTAD, 2006). Although concentration per se does not imply negative welfare effects, a number of open questions in this area need further study. When innovation is central, however, welfare considerations ought to include the ex ante perspective of what incentives are suitable to bring forth desired research efforts. IPRs are crucial for private R\&D investments in fields (such as biotechnology) in which innovations are easily copied (a predicament that actually applies to traditional germplasm as well). If private R\&D is to be relied upon for major agricultural biotechnology innovations, as the global trend to a diminished role of public support for agricultural research suggests, the privatisation of some critical research output may be inevitable.

Assessing the net economic value of efficiency-enhancing innovations is typically done by estimating the associated changes in producer and consumer surpluses in a partial equilibrium setting (Alston et al., 1995). But because of the proprietary nature of GM innovations, there is a need to account for market power in the quantitative evaluation of the welfare impact of innovation adoption (Moschini and Lapan, 1997). Earlier studies that accounted for this issue documented sizeable efficiency gains from new GM crops (FalckZepeda et al., 2000; Moschini et al., 2000) and showed that these economic benefits were shared by farmers, innovators and consumers. ${ }^{8}$ In particular, with reference to the market power and IPR issues discussed earlier, it was found that agro-biotechnology innovators typically capture only a fraction of the expost benefits of GM innovations. These studies, in any case, did not attempt to include the possible externality effects of GM crops. As noted earlier, the evidence to date points to a net positive environmental impact of GM crops. Thus, explicit accounting of such external effects (the quantitative evaluation of which is clearly a difficult task) would reinforce the foregoing results concerning the positive welfare impacts of GM crops.

\footnotetext{
${ }^{7}$ Monsanto, for example, underwent a remarkable transformation from an agro-chemical concern without any seed business to the largest seed company in the world.

${ }^{8}$ For example, the welfare gains from worldwide adoption of HR soybeans were estimated by Moschini et al. (2000) to exceed $\$ 2$ billion per year, with innovators capturing 37 per cent of that, farmers receiving 22 per cent, and consumers claiming 41 per cent.
} 


\subsection{The product differentiation hypothesis}

The conclusions of the foregoing studies are predicated upon the assumption that the new GM crops are merely more efficient but otherwise equivalent to traditional varieties. This assumption is seemingly at odds with the observation of opposition by some segments of the public, suggesting a degree of consumer resistance to the new GM crops. Taking such a hypothesis at face value implies that, from a consumer perspective, food products manufactured with the new GM crops are only imperfect substitutes for the corresponding conventional products - indeed, they provide an inferior quality relative to traditional foods in the vertical product differentiation (VPD) sense (see Mussa and Rosen, 1978). The fact that GM food is thus a 'weakly inferior' substitute for conventional food affects the potential welfare impact in at least two ways. First, it implies a smaller potential market for the new GM products. Second, and more subtly, to deliver traditional GM-free food in the post-GM world, additional costs must be incurred (relative to the pre-innovation situation). That is, costly (and hitherto unnecessary) segregation and identity preservation activities are required if the two types of food (GM and non-GM) are to be differentiated in the market. The GM innovation process, therefore, has also introduced a new market failure, a type of externality on the production of traditional food products (Lapan and Moschini, 2004).

Models that account for such VPD consumer preferences, and the need for segregation and identity preservation to achieve the desired product differentiation between GM and non-GM products, have found that the welfare implications of introducing firstgeneration GM crops can be ambiguous (Fulton and Giannakas, 2004; Lapan and Moschini, 2004; Lence and Hayes, 2005; Sobolevsky et al., 2005). This situation is not a standard aggregate externality in the sense that, to a first approximation, the negative impacts of GM crop adoption depend on the fact that some GM crops are being grown at all, and less so on the extent of GM crop cultivation. ${ }^{9}$ Put another way, this external effect essentially induces a nonconvexity in the aggregate production set. Given this external effect, one can no longer presume that the competitive equilibrium achieves Pareto efficiency, which provides grounds for policy intervention. But if the nonconvexity argument is the crux, what might be called for is a ban on the new technology rather than policies that affect adoption at the margin.

\footnotetext{
${ }_{9}^{9}$ Bullock and Desquilbet (2002) find that a major resource cost of segregation and identity preservation is due to the flexibility loss of having to move from one to two handling channels (one for GM products and one for non-GM products).
} 
That is, having approved a given GM product, it may be desirable to have a larger rather than smaller diffusion. In particular, disincentives to the (marginal) adoption of GM products (as might be the case for some EU coexistence measures discussed later) decrease aggregate welfare (see Moschini et al., 2005). In any event, the conclusion that otherwise efficiency-enhancing innovations might have detrimental net welfare effects depends critically on the extent of consumers' aversion to GM products, a question that is discussed next.

\subsection{Assessing consumer response to GM food}

To what extent are GM products weakly inferior from the consumers' viewpoint? The foregoing market studies do not provide an independent quantitative assessment of this effect; they simply assume that it might exist and calibrate parametric scenarios to illustrate possible impacts. To estimate consumers' actual differential valuation of (otherwise equivalent) GM and non-GM products, ideally one would want to rely on observed consumer behaviour in a real market setting. That not being typically possible, economists have borrowed from valuation techniques used in environmental economics (contingent valuation and experimental methods) to assess consumers' willingness to pay (WTP) for the non-GM attribute. Despite the sheer volume of work accumulated to date, however, it is difficult to decide just what we know about the question of interest.

Contingent valuation (stated preference) suffers from well-known drawbacks, the foremost one perhaps being its 'hypothetical bias' whereby the lack of real economic commitment to a transaction inflates stated WTP values (Neill et al., 1994). Experimental methods have the potential to improve on that, and their use has become quite popular to assess consumers' preferences vis-à-vis GM and non-GM products. Often this takes the form of an experimental auction setting where subjects bid for the possibility to exchange a GM item (such as a chocolate-chip cookie or a bag of potato chips) for the corresponding nonGM good, leading to a direct elicitation of the subjects' W'TP. Alternatively, subjects can exchange a given non-GM item for the corresponding GM good, leading to the elicitation of a willingness to accept (WTA) value. Lusk et al. (2005) summarise the results from 25 such earlier studies (providing 57 valuations) and find non-negligible premia for non-GM foods (e.g., the simple average of the non-GM premium over all observations, but excluding one clear outlier, was found to be 29 per cent). But much variability is found in these GM 
valuation results, and even within a single study considerable heterogeneity exists. For example, Noussair et al. (2004) found that, even for French consumers (who, according to consumer-attitude studies, are notoriously anti-GM), about one-quarter of them are indifferent and about two-thirds are willing to buy GM products at some price.

Although the revealed-preference nature of experimental methods might be more appealing than the stated preference of contingent valuation surveys, exactly how one can translate such results to the market remains an open question. As Levitt and List (2007: 170) put it, 'Perhaps the most fundamental question in experimental economics is whether findings from the lab are likely to provide reliable inferences outside of the laboratory'. In some instances (as, for example, when the experiment is serving a methodological purpose, such as comparing different game-theoretic solution concepts), this 'generalisability' issue may not be important. But when, as in our case, the object of interest concerns a quantitative assessment of the consumers' expected buying behaviour for GM products, generalisability is critical, and a number of considerations suggest that the existing applied studies may not provide reliable enough estimates. For example, the large difference between WTP and WTA measures found in existing studies, documented in Lusk et al. (2005), is difficult to rationalise for a setting that, by construction, should have an income effect that is essentially nil. ${ }^{10}$ Also problematic is the finding that subjects are willing to pay large private amounts for what is essentially a public good (e.g., environmental benefits) (Lusk et al., 2004). ${ }^{11}$

The value of the non-GM attribute elicited for a given subject in a given experiment, in addition to being highly sensitive to the particular experimental setting, likely reflects the idiosyncratic nature of the information possessed by the subject. Rousu et al. (2007) find that information (both for and against GM) can be critical in shaping the subjects' WTP for nonGM. In addition to establishing that verifiable information provided by third parties might improve welfare, as noted by the authors, this finding also suggests that extrapolating experimental results to a market setting-where consumers' information is continuously

10 Because a large divergence between WTP and W'TA is common, WTA is usually avoided in contingent valuation studies. Harrison (2006) calls this situation embarrassing and suggests that bestpractice experimental methods should be able to improve on that.

${ }^{11}$ In fact, Noussair et al. (2004) postulated that one reason their experimental results did not match the more negative picture arising from consumer attitude surveys was precisely that the latter are likely to elicit a response that includes consumers' assessment of the externality, whereas bidding behaviour in an experiment likely focuses on the private value of the object (as standard theory would imply). 
updated and where consumers' habit formation may lead to considerable divergence between immediate and long-run behaviour-may indeed be tricky. The role of information is also stressed by Knight et al. (2007), whose marketing study carried out in seven countries suggests that GM products may be more acceptable than reported in previous studies.

The possibility that consumer attitude studies and experimental studies might in fact provide limited guidance as to actual consumers' purchasing behaviour vis-à-vis GM products is also stressed by Kalaitzandonakes et al. (2005). Using scanner data on actual purchases, they find that consumers in the Netherlands did not alter their shopping choices for a period (1997-2000) in which some GM-labelled products were actually labelled along with corresponding non-GM goods. Indirect corroborating evidence is offered by the US experience with the use of recombinant bovine somatotropin (rbST) in milk production. Considerable controversy surrounded the approval process and introduction of this technology in 1994. Pre-commercialisation surveys documented widespread concerns about safety, leading to predictions of a sizeable drop in milk demand following the introduction of rbST. Such predictions turned out to be incorrect, however, as the evidence shows that the (unlabelled) introduction of rbST did not affect actual milk purchasing decisions (Aldrich and Blisard, 1998).

The presumption that consumer demand might be significantly affected by firstgeneration GM products clearly needs further scrutiny. The possibility that consumers' unfettered preferences can be revealed through market transactions, however, is heavily constrained by many features of existing GM regulations.

\section{The regulation of GM crops}

GM crops and their products are subject to a host of national regulations around the world.

The United States, with its 1986 Coordinated Framework for Regulation of Biotechnology, chose to rely on pre-existing laws and federal agencies (Pew Initiative, 2004). The stated overriding principle is that the use of biotechnology is not risky per se, so that it is not the 'process' but rather the 'product' that should be the object of interest. Still, the USDA presumption is that GM plants might be plant pests, so that they are considered 'regulated articles' and require authorisation for environmental release (for example, field tests). Upon 
successful experimental release, a GM crop can obtain non-regulated status, ${ }^{12}$ after which it can be freely commercialised without further specific oversight. In the deregulation process, a substantial amount of information on the food and environmental safety of a GM crop is developed and shared with regulators. The US Food and Drug Administration (FDA) does not require premarket approval for food that is 'generally recognised as safe' (GRAS), a determination that is the responsibility of the party putting the product on the market. Because food produced from (first-generation) GM crops is deemed substantially equivalent to conventional food, the GRAS status essentially follows. Nonetheless, GM crop developers have, in all cases to date, submitted detailed safety and nutritional assessments to FDA scientists under a voluntary consultation procedure.

The EU views GM crops and products as fundamentally novel and in need of an ad hoc regulatory structure. The earlier process of GM crops approval was put on hold in 1998 with a de facto moratorium that led, among other things, to a World Trade Organisation (W'TO) dispute brought by the United States, Canada and Argentina. ${ }^{13}$ The new regulatory framework developed since then, which became fully operational in 2004, is rather complex: it draws upon a number of directives and regulations and it involves decision roles for both national authorities and EU-level bodies (European Union, 2006). The main instrument is Regulation (EC) No 1829/2003, which provides for a single procedure (the one door, one key principle) for new authorisations of GM food and feed in the EU. A single risk assessment process is envisioned, under the aegis of the European Food Safety Authority (EFSA), which is responsible for the scientific assessment of both environmental risk and (human and animal) health risk. Next, for the risk management stage, based on the opinion of EFSA, the European Commission makes a proposal on the granting or refusal of the authorisation, which must be approved by member states (through a standing committee operating under the qualified majority rules). If member states fail to agree, the matter is referred to the Council of Ministers and, upon failure to resolve the impasse, the Commission has a final decision opportunity.

\footnotetext{
12 Only for plants modified to express pharmaceutical or industrial traits is no deregulation envisioned at present.

13 The final WTO ruling, published in September 2006, essentially upheld the central claims against the EU, although the implications of these findings turned out to be moot in light of the recent overhaul of EU policies and procedures dealing with GM crop approvals.
} 
The differences between the US and EU approval processes are perhaps most evident at the risk management stage, where the EU displays a deeper and more complex political oversight. But the EU also implements two major types of post-market regulations: mandatory GM labelling and coexistence measures. Since April 2004, products consisting of or containing GM organisms and food products obtained from GM organisms are subject to mandatory labelling and traceability requirements as established in Regulation (EC) 1830/2003 (European Union, 2006). ${ }^{14}$ These labelling rules also apply to animal feed. To avoid the GM label, the content of (authorised) GM product must not exceed 0.9 per cent, provided the presence of this material is adventitious or technically unavoidable. Traceability is a general requirement under the EU General Food Law 178/2002, but Regulation (EC) 1830/2003 sets out more specific and onerous requirements for GM products. Coexistence is articulated in Recommendation 2003/556/EC, which provides 'guidelines for the development of national strategies and best practices to ensure the coexistence of genetically modified crops with conventional and organic farming' (European Commission, 2003: 36). The main concern is adventitious contamination at the farm level as may arise from using impure seed lots, ${ }^{15}$ cross-pollination and sharing of harvesting machinery. Measures contemplated include spatial isolation (such as mandatory isolation distances between GM and non-GM plots, use of buffer strips) and time isolation (JRC-IPTS, 2006). The stated intention of coexistence measures is to address economic and marketing implications, not safety issues (which are assumed to have been dealt with at the approval stage).

Many countries have or are introducing their own GM product regulations with measures that fall within the spectrum of options delineated by the US and EU approaches. Harmonisation of such measures is proving a challenging undertaking, as several international bodies claim some say in the matter. The Codex Alimentarius is a commission charged with developing standards for food safety. These standards are voluntary, although they provide the usual benchmark for national policies and for the WTO. But the GM food issue is proving unyielding for the Codex, and no conclusive guidance is emerging. The WTO itself has a stake in preventing the misuse of national regulations as nontariff barriers to

\footnotetext{
${ }^{14}$ Such items must carry a label stating something like 'This product contains genetically modified organisms'. Products such as meat or milk obtained from animals fed with genetically modified feed are exempt.

15 An unresolved issue, in this context, is that no specific tolerance level for the adventitious comingling of non-GM seed has been agreed upon.
} 
trade. ${ }^{16}$ The still unfinished case brought against the EU policies in 2003, which did not pertain to the newer mandatory labelling and coexistence measures, may yet give way to a broader challenge. In this respect, the implications of the EU regulatory policies spill over its own borders, as exporting countries are wary of the impact their GM-related actions can have on access to the EU market.

\subsection{Are GM products overregulated?}

As the foregoing review illustrates, GM crops typically must undergo pre-market evaluations and approvals that traditionally bred crop varieties can eschew. But the prevailing scientific view on this matter is that the use of recombinant DNA techniques in crop breeding does not, per se, produce more risky crops (see, for example, Bradford et al., 2005). New biotechnology techniques might actually provide a higher degree of control of DNA manipulations that have always been part and parcel of crop breeding. This scientific viewpoint argues that it is illogical to subject GM crops to a much higher degree of scrutiny than traditionally-bred crops because the use of gene splicing does not entail any unique risk (Miller and Conko, 2004). That is, from the perspective of human or environmental risk, it is not the process but rather the product that matters. This perspective on risk regulation calls for proportionality of measures with the objective risk at hand, and for consistency (McHughen, 2007). Such consistency often appears to be missing when it comes to GM crop regulation. For example, mutation breeding-whereby random mutations in a plant's genome are induced by such disruptive techniques as irradiation-is typically accepted as less risky than gene splicing and in need of none of the scrutiny required of GM crops. ${ }^{17}$

Insofar as the current regulatory structure leads to equivalent hazards being treated very differently, negative welfare consequences obviously follow. In particular, singling out certain new products for undue regulation can distort incentives for $\mathrm{R} \& \mathrm{D}$ and affect the flow of innovation, with negative welfare effects in the long run. In the case of GM crops, there is some evidence that regulatory compliance costs are very high (Kalaitzandonakes $e t$

\footnotetext{
${ }_{16}$ The Cartagena Protocol on Biosafety, drafted in the context of the UN Convention on Biological Diversity, also claims influence on the transboundary movement of GM products (therein labelled living modified organisms) intended for environmental release.

17 Also known as mutagenesis, this technique has been used to develop more than 2,200 commercialised plant varieties (Bradford et al., 2005). Mutagenesis is explicitly exempt from the EU regulation of GM products.
} 
al., 2007). The high cost of regulatory approval, in particular, might make it prohibitive for small firms and public research labs (like universities) to bring new varieties to market, which might skew the portfolio of commercially available varieties in favour of large seed companies (and thus contribute to the sort of industry consolidation, referred to earlier, that gives rise to concern).

\subsection{What is a sensible GM labelling policy?}

A number of countries have introduced or are considering GM labelling requirements (Gruère and Rao, 2007), but the sweeping attributes of the EU labelling rules stand out. Their mandatory nature, in particular, is in sharp contrast with the regulatory approach pursued in Canada and the United States, where at most a voluntary GM labelling system is envisioned. ${ }^{18}$ Given the presumption that pre-approval risk assessment and management allows only safe GM products on the market, from an economics perspective the remaining role for labelling is that of allowing a successful product differentiation (vis-à-vis the GM and non-GM attributes) for the benefit of the consumer. Thus, labelling deals with the asymmetric information problem that might lead to the market failure originally described by Akerlof (1970).

The crucial question is whether labelling should be voluntary and pertain to a perceived positive attribute (i.e., non-GM) or mandatory for the presumed negative attribute (GM). Both labelling systems can convey the same information to consumers. A coherent labelling policy, however, must consider that the relevant information of interest to the consumer (i.e., the non-GM nature of the superior product) here needs to be produced by costly segregation, identity preservation and systematic testing, and that it is the providers of the non-GM product who have the best incentives to undertake such activities effectively (Moschini and Lapan, 2006). The standard conclusion, therefore, is that voluntary labelling of the non-GM attribute is preferable from an economics perspective (e.g., Golan et al., 2001). Indeed, the cases of organic food and of kosher food provide two excellent examples of successful voluntary labelling programs in similar settings.

\footnotetext{
18 Also, the threshold level to avoid labelling ( 0.9 per cent) is very strict when compared with the purity levels for GM labelling used by other countries (e.g., South Korea and Japan use a 3 per cent and a 5 per cent threshold, respectively). Lapan and Moschini (2007) relate the determination of a purity level for the purpose of GM labelling to the theory of grading and minimum quality standards in an explicit model with VPD preferences.
} 
A problem with mandatory GM labelling is its justification by appeal to the consumers' 'right to know', a motivation explicitly underlying the EU approach. Such a generic right-to-know is too open-ended and potentially unbounded (it can be invoked for virtually anything), and it does not compare favourably to the more compelling 'need to know' rationale when viewed in the context of risk communication. In fact, labels are also routinely used, and often mandated, to warn consumers of specific hazards (e.g., warning labels on cigarettes). Viscusi (1998: 28) notes that mandating information disclosure through labelling gives 'policymakers an intermediate policy option when there is insufficient evidence to warrant direct regulation, but enough concern about the potential risk to alert the public of the need for care'. The variety of opinions expounded in the popular media on the safety of GM food could, given the level of scientific literacy of the typical consumer, lead the public to infer that if authorities require the labelling of GM food, then there might indeed be a risk in consuming it. Hence, the stigmatising effect of mandatory labelling of GM food is itself bound to affect consumer perception of risk and make food retailers wary of carrying and selling GM food.

One specific aspect of the EU labelling rules that is questionable relates to the need to label GM foods regardless of whether or not DNA or proteins derived from genetic modification are contained in the final product (so that the GM labelling requirement also pertains to highly refined products, such as vegetable oil). At the same time, the rules distinguish between such products, held to be produced 'from' a GM source, and something produced 'with' the aid of a GM product, which need not be labelled. This subtle distinction turns out to be rather important because it exempts cheese, when produced with chymosin obtained from GM microorganisms, from having to carry a GM label. ${ }^{19}$

\subsection{The problem of coexistence}

One of the stated principles of the EU recommendations on coexistence is that farmers 'who introduce the new production type should bear the responsibility of implementing the farm management measures necessary to limit gene flow' (European Commission, 2003: 41). This clearly envisions a strong assignment of property rights. On the one hand, such clarity

19 Traditionally obtained as rennet (rendered from the stomach of milk-fed calves), chymosin is an enzyme essential in cheese production that can now be produced from GM bacteria or yeast. In the $\mathrm{EU}$, chymosin was the first enzyme from a GM source to be approved for use in food preparation, and it is now widely used in cheese production. 
might be welcomed, as the bilateral externality that measures such as buffer strips and isolation distances are meant to address falls within the scope of the celebrated Coase theorem (Beckmann and Wesseler, 2007). Specifically, costless bargaining between GM adopters and non-adopters should lead to an efficient allocation of land, involving strong regional agglomeration of GM and non-GM production areas, regardless of the particular assignment of property rights. In practice, however, transaction costs and informational asymmetries are likely to make that argument moot, and putting the onus of farm-level coexistence on GM farmers alone is likely to negatively impact GM adoption. Some of the proposed rules are extremely restrictive and arguably prohibitive for prospective GM crops adopters (Demont et al., 2008). In particular, strict local ex ante regulations invoked under the notion of coexistence, at times including the need for prior approval for GM plots, and uncertainty about the implied potential liability issues may provide strong deterrence to farmers' adoption of GM crops (Beckmann et al., 2006).

A simpler (arguably more market-oriented) alternative for coexistence would place on non-GM producers the onus of ensuring adequate purity (as defined by GM labelling) of the non-GM product. Given the heterogeneity of production conditions, and the stochastic nature of the potential contamination problem that coexistence measures intend to prevent, a non-GM farmer may be the best positioned to determine what measures are necessary to meet the target purity level. One should also re-emphasise that coexistence measures are not meant to keep risky products out of the market (an issue for the GM product approval stage), but are best viewed in the context of the induced product differentiation hypothesis. Preventing contamination at the farm level is only one step in a marketing and processing chain that needs to rely on segregation and identity preservation activities if a credible nonGM product, in an environment where both GM and non-GM crops are grown, is to be delivered to consumers. Throughout that chain, the incentive for efficient diligence rests with the operators that pursue the marketing of the (superior) non-GM product, and thus it seems desirable to align the incentives at the farm level with those of the entire supply chain.

\section{Some current issues}

The current regulation of GM crops, including some associated policy uncertainty, appears to be a major factor for the future development and adoption of GM products and bears heavily on how biotechnology will affect the development of food markets. In Europe, in 
particular, the climate remains unfriendly to GM products. Much has been written to explain the roots of that hostility (see, for example, Scholderer, 2005), with considerations ranging from the lingering impact of some food safety scandals (such as the bovine spongiform encephalopathy crisis), exacerbating a low public confidence in food safety authorities, to a culturally ingrained scepticism towards science, which some relate to the adoption of the 'precautionary principle' for risk regulation. Other possible explanations might point to political economy arguments, including old-fashioned trade protectionism (Lapan and Moschini, 2004) as well as the desire to protect the interests of established European agrochemical firms heavily invested in traditional crop-protection technologies (Anderson and Jackson, 2006; Graff and Zilberman, 2007).

Appeals to the precautionary principle to rationalise European GM policies, in particular, need further scrutiny. From a positive perspective, in a broader context, there is no evidence that risk regulations in Europe are systematically more risk-averse and precautionary than those of the United States (Hammitt et al., 2005). From a normative perspective, the economics of the precautionary principle emphasises rational decision making in the face of uncertainty, risk and the possibility of learning, and a variety of prescriptions for action (some of which are in stark contrast with each other) are possible, depending on how one frames the decision problem (e.g., Gollier, 2001; Hennessy and Moschini, 2006). The choice between the newer technology of GM crops and otherwise modern (chemically dependent) agricultural practices with traditional varieties cannot be construed as a choice between a 'risky' alternative and a 'safe' one. There are risks associated with adopting GM crops, just as there are risks in rejecting them, and the real question should concern the balance of the perceived benefits and risk tradeoffs (Zilberman, 2006).

Leaving aside the structure of GM regulation, the timeliness of its implementation matters as well. In the three years since resuming GM trait approval in 2004, only nine new events have been approved in the EU (more than 30 are lingering in the pipeline), of which none is for actual cultivation (USDA, 2007). ${ }^{20}$ Furthermore, a number of member states continue to implement GM product bans that conflict with the EU's own approved products. One implication of the EU reluctance to implement its own GM rules is the

\footnotetext{
${ }^{20}$ For all these cases, a qualified majority of the member states did not materialise, despite a positive risk assessment of the EFSA, and the Council did not make a decision, so that in the end these authorisations were granted by the Commission itself.
} 
growing divide that is emerging between approved GM traits in the EU vis-à-vis approved traits in other major producing and exporting countries. For example, as of March 2008, 14 of 24 traits or trait-stacks being commercialised in US maize seed for the 2008 growing season do not have either EU food or feed approval (10 out of 24 have neither) (US National Corn Growers Association). This situation of 'asynchronous' GM trait approvals, coupled with the effective zero tolerance on unapproved traits envisioned by the current EU regulations, is putting considerable stress on EU imports of feed products. The trend for these asynchronous approvals is not promising, as major producing areas outside the United States are also poised for widespread adoption of stacked-gene GM varieties, most of which are still unapproved in the EU. All this contributes to higher feed and food prices, and to a loss of competitiveness for the EU livestock industry, as the Commission's own study recently articulated (European Commission, 2007). ${ }^{21}$

In addition to the implications of the process of GM trait approval just discussed, post-market regulations of GM products are having a direct effect on EU food markets. In short, essentially no labelled GM product is to be found in European grocery stores. Retail chains are particularly leery of being singled out by anti-GM activists. The relevance of private labels in the retailing strategy of major firms heightens the risks of a possible brand tarnishing. Given this, it appears that the food industry has responded to the overarching GM regulatory structure by developing supply chains that simply exclude GM products (and often implement private procurement standards that are tighter than those mandated by current regulation). The strategic equilibrium in the food industry thus engineered is scarcely different from a collusive outcome. In the end, the mandatory labelling of GM products implemented by the EU seems to achieve the opposite of its purported objective: instead of providing consumers with a meaningful right to choose, it is tantamount to a de facto ban on retailing of GM products. Similarly, the restrictive coexistence rules that are emerging in the EU increase the costs of adopting GM products to possibly prohibitive levels.

\footnotetext{
21 An additional perspective on the spillover effects of EU-style regulations points to the problems, for developing countries, of adopting unnecessarily restrictive GM regulations. Paarlberg (2008), in particular, sees this as a very serious problem for African countries and argues that is could significantly undermine the potential role of biotechnology in helping solve the food problem of the very poor.
} 


\section{Conclusion}

Concerns about food procurement have always mattered, and still do. The global food balance equation, in the coming years, will be affected by the confluence of a number of secular trends. Population growth and income growth in developing countries are expected to sustain a strong global demand increase for agricultural output. The challenge of meeting such demand growth is compounded by the expansion of (subsidised) biofuel production in the United States and elsewhere, with its associated withdrawal of a large amount of land from food production, as well as the uncertainties of emerging global climate changes. Technological innovation, as for much of recent human history, will be needed to ensure that basic food needs are met in an efficient fashion. No single innovation can, of course, be expected to address all that. But recent advances, and current research, in the biosciences leave no doubt that biotechnology can play a critical role.

A number of economic studies have shown that the extensive adoption of firstgeneration GM crops in large agricultural producing regions has resulted in impressive productivity gains, as well as providing a number of environmental benefits, and the welfare gains attributable to GM innovations have been shared broadly among producers, consumers and innovators. Observers often lament that earlier GM products did not offer tangible benefits to consumers, but economists must disagree. The (ceteris paribus) price decrease that is induced by gains in production efficiency does benefit consumers, and even more so for low-income consumers whose food share of total expenditure is higher. Forgoing GM technology inevitably raises food prices. This is bad for society at large, and it is a particularly regressive policy that penalises less affluent citizens. The recent spikes in the prices of basic agricultural commodities, and what this means for the food security of the poor, might help foster a more balanced consideration of the positive impacts of agricultural productivity gains due to GM crops.

First-generation GM technology has proven safe and effective, it has been enthusiastically adopted by farmers in some developed and developing countries and it is likely to have lasting effects on agriculture (Economist, 2008). Indeed, more is expected from agro-food biotechnology. Effective insect and weed control strategies embedded in the crops' own genetic attributes are expected to become available for major crops (such as rice) so far not commercially affected, and GM improvements will tackle important abiotic stresses, such as the effects of drought conditions. In addition, second-generation GM crops 
engineered for specific output attributes are expected to introduce novel food products that offer consumers nutritionally improved options that could have a variety of health benefits. But, as the economics of innovation would suggest, such advancements do not happen in a vacuum. A full harvest of biotechnology's promises in the agro-food setting still requires a commitment to R\&D, and, insofar as a critical amount of that effort needs to be carried out by the private sector, it needs an environment that welcomes the contributions of biotechnology and that promotes the adoption of better and safer products.

Serious concerns about how that might play out in Europe are legitimate. GM crops, and products thereof, are highly regulated everywhere, but the stringency of EU regulations in this setting, and the vagaries of their implementation, represents an objective obstacle to GM product adoption, contributes to an increasing disharmony in international standards, which affects trade, and acts as a disincentive for sustained biotechnology R\&D efforts in the agro-food sector. The unresolved problems that affect biotechnology regulation reflect, to a degree, a number of concerns that have dogged this technology from its early days. But as some initial fears and anxieties have been resolved by the accumulated evidence of science and rational analysis, the rigidities that in the meantime have been built into the regulatory system might have a lasting detrimental effect. That this is having undesirable consequences is apparent. Whether the current structural obstacles can yet be effectively resolved so as to make the 'European strategy' a success remains to be seen. 


\section{References}

Akerlof, G. A. (1970). The market for lemons: Quality uncertainty and the market mechanism. Quarterly Journal of Economics 84: 488-500.

Aldrich, L. and Blisard, N. (1998). Consumer acceptance of biotechnology: Lessons from the rbST experience. Agriculture Information Bulletin No. 747-01. Washington, D.C.: Economic Research Service, USDA.

Alston, J. M., Norton, G. W. and Pardey, P. G. (1995). Science under Scarcity: Principles and Practice of Agricultural Research Evaluation and Priority Setting, Ithaca, NY: Cornell University Press.

Anderson, K., and Jackson, L.A. (2006). Transgenic crops, EU precaution, and developing countries. International Journal of Technology and Globalisation 2: 65-80.

Beckmann, V., Soregaroli, C. and Wesseler, J. (2006). Coexistence rules and regulations in the European Union. American Journal of Agricultural Economics 88: 1193-1199.

Beckmann, V. and Wesseler, J. (2007). Spatial dimension of externality and the Coase theorem: Implications for coexistence of transgenic crops. In Heijman, W. (ed), Regional Externalities. New York: Springer Publishers, 223-242.

Bellwood, P. (2005). First Farmers - The Origin of Agricultural Societies. Oxford: Blackwell Publishing.

Berg, P., and Singer, M. F. (1995). The recombinant DNA controversy: Twenty years later. Proceedings of the National Academy of Sciences of the United States of America 92: 9011-9013.

Bradford, K. J., Van Deynze, A., Gutterson, N., Parrott, W. and Strauss, S. H. (2005). Regulating transgenic crops sensibly: lessons from plant breeding, biotechnology and genomics. Nature Biotechnology 23:439-444.

Bullock, D., and Desquilbet, M. (2002). The Economics of Non-GMO Segregation and Identity Preservation. Food Policy 27: 81-99.

Charles, D. (2002). Lords of the Harvest: Biotech, Big Money, and the Future of Food. Cambridge, MA: Perseus Publishing.

Cohen, M. N. (1977). The Food Crisis in Prehistory - Overpopulation and the Origin of Agriculture. New Haven, CT: Yale University Press.

Demont, M., Daems, W., Dillen, K., Mathijs, E., Sausse, C. and Tollens, E. (2008).

Regulating coexistence in Europe: Beware of the domino effects! Ecological Economics 64: 683-689. 
Diamond, J. (2002). Evolution, consequences and future of plant and animal domestication. Nature 418: 700-707.

Economist (2008). The next green revolution-Europe may not like it, but genetic modification is transforming agriculture. The Economist, February 23: 81-82

Evenson, R. E. and Gollin, D. (2003). Assessing the impact of the green revolution, 1960 to 2000. Science 300: 758-762.

European Commission (2002). Life Sciences and Biotechnology - A Strategy for Europe, Communication from the Commission, $\operatorname{COM}(2002) 27$.

European Commission (2003). Commission recommendation of 23 July 2003 on guidelines for the development of national strategies and best practices to ensure the coexistence of genetically modified crops with conventional and organic farming. Official Journal of the European Communities L 189: 36-47, 29 July.

European Commission (2007). Economic Impact of Unapproved GMOs on EU Feed Imports and Livestock Production. Directorate-General for Agriculture and Rural Development.

European Union (2006). Questions and Answers on the Regulation of GMOs in the EU. Document updated 7 July 2006.

Falck-Zepeda, J. B., Traxler, G. and Nelson, R. G. (2000). Surplus distribution from the introduction of a biotechnology innovation. American Journal of Agricultural Economics 82: $360-69$.

Fernandez-Cornejo, J. and Caswell, M. (2006). The First Decade of Genetically Engineered Crops in the United States. Economic Information Bulletin No. 11. Washington, D.C.: Economic Research Service, USDA.

Fulton, M. and Giannakas, K. (2004). Inserting GM products into the food chain: The market and welfare effects of different labeling and regulatory regimes. American Journal of Agricultural Economics 86: 42-60.

Gardner, B. L. (2002). American Agriculture in the Twentieth Century. Cambridge, MA: Harvard University Press.

Gaskell, G. et al. (2006). Europeans and Biotechnology in 2005: Patterns and Trends.

Eurobarometer 64.3, final report to the European Commission's Directorate-General for Research.

Golan, E., Kuchler, F. and Mitchell, L. (2001). Economics of food labeling. Journal of Consumer Policy 24: 117-184. 
Gollier, C. (2001). Should we beware of the precautionary principle? Economic Policy 16: 302321.

Gómez-Barbero, M. and Rodríguez-Cerezo, E. (2007). GM crops in EU agriculture. Case study for the BIO4EU project, European Commission.

Graff, G.D. and Zilberman, D. (2007). The political economy of intellectual property: Reexamining European policy on plant biotechnology. In J.P. Kesan, ed., Agricultural Biotechnology and Intellectual Property: Seeds of Change. Cambridge, MA: CAB International, 244-267.

Gruère, G. P. and Rao, S. R. (2007). A review of international labeling policies of genetically modified food to evaluate India's proposed rule. AgBioForum 10: 51-64.

Hammitt, J. K., Wiener, J. B., Swedlow, B., Kall, D. and Zhou, Z. (2005). Precautionary regulation in Europe and the United States: A quantitative comparison. Risk. Analysis 25: 1215-1228.

Harrison, G. W. (2006). Experimental evidence on alternative environmental valuation methods. Environmental \& Resource Economics 34: 125-162.

Hennessy, D. and Moschini, G. (2006). Regulatory actions under adjustment costs and the resolution of scientific uncertainty. American Journal of Agricultural Economics 88: 308-323.

Herdt, R. W. (2006). Biotechnology in agriculture. Annual Review of Environment and Resources 31: $265-295$.

Huang, J., Hu, R., Rozelle, S. and Pray, C. (2005). Insect-resistant GM rice in farmers' fields: Assessing productivity and health effects in China. Science 308: 688-690.

Huffman, W. E. and Evenson, R. E. (1993). Science for Agriculture - A Long-term Perspective. Ames, IA: Iowa State University Press.

ICSU (2003). New Genetics, Food and Agriculture: Scientific Discoveries-Societal Dilemmas. International Council for Science.

JRC-IPTS (2006). New Case Studies on the Coexistence of GM and Non-GM Crops in European Agriculture. European Commission Joint Research Centre, Institute for Prospective Technologies Studies (JRC-IPTS).

Kalaitzandonakes, N., Marks, L. A. and Vickner, S .S. (2005). Sentiments and acts towards genetically modified foods. International Journal of Biotechnology 7: 161-177.

Kalaitzandonakes, N, Alston, J. and Bradford, K. J. (2007). Compliance costs for regulatory approval of new biotech crops. Nature Biotechnology 25: 509-5011. 
Knight, J. G., Mather, D. W., Holdsworth, D. K. and Ermen, D. F. (2007). Acceptance of GM food-an experiment in six countries. Nature Biotechnology 25: 507-508.

Lapan, H. E. and Moschini, G. (2004). Innovation and trade with endogenous market failure: The case of genetically modified products. American Journal of Agricultural Economics 86: 634-648.

Lapan, H. E. and Moschini, G. (2007). Grading, minimum quality standards, and the labelling of genetically modified products. American Journal of Agricultural Economics 89: 769-783.

Lence, S. and Hayes, D. (2005). Genetically modified crops: Their market and welfare impacts. American Journal of Agricultural Economics 87: 931-950.

Levitt, S. D. and List, J. A. (2007). What do laboratory experiments measuring social preferences reveal about the real world? Journal of Economic Perspectives 21: 153-174.

Lusk, J. L., House, L.O., Valli, C., Jaeger, S. R., Moore, M., Morrow, B. and Traill, W. B. (2004). Effect of information about benefits of biotechnology on consumer acceptance of genetically modified food: Evidence from experimental auctions in the United States, England, and France. European Review of Agricultural Economics 31: 179-204.

Lusk, J. L., Jamal, M., Kurlander, L., Roucan, M. and Taulman, L. (2005). A meta-analysis of genetically modified food valuation studies. Journal of Agricultural and Resource Economics 30: $28-44$.

McHughen, A. (2007). Fatal flaws in agbiotech regulatory policies. Nature Biotechnology 25: 725-727.

Miller, H. I. and Conko, G. (2004). The Frankenfood Myth—How Protest and Politics Threaten the Biotech Revolution. Westport, CT: Praeger Publishers.

Moschini, G. (2004). Intellectual property rights and the World Trade Organization: Retrospect and prospects. In Anania, G., Bohman, M., Carter, C. and McCalla, A. (eds), Agricultural Policy Reform and the WTO. Aldershot, UK: Edward Elgar Publishing, 474-511.

Moschini, G. (2006). Pharmaceuticals and industrial traits in genetically modified crops: Coexistence with conventional agriculture. American Journal of Agricultural Economics 88: 1184-1192.

Moschini, G., Bulut, H. and Cembalo, L. (2005). On the segregation of genetically modified, conventional and organic products in European agriculture: A Multi-market 
equilibrium analysis. Journal of Agricultural Economics 56: 347-372. (Erratum, Journal of Agricultural Economics 58: 393.)

Moschini, G. and Lapan, H. (1997). Intellectual property rights and the welfare effects of agricultural R\&D. American Journal of Agricultural Economics 79: 1229-42.

Moschini, G. and Lapan, H. (2006). Labeling regulations and segregation of first- and second-generation GM products: Innovation incentives and welfare effects. In Just, R. E., Alston, J., and Zilberman, D. (eds), Regulating Agricultural Biotechnology: Economics and Policy. New York: Springer Publishers, 263-282.

Moschini, G., Lapan, H. and Sobolevsky, A. (2000). Roundup ready soybeans and welfare effects in the soybean complex. Agribusiness 16: 33-55.

Mussa, M., and Rosen, S. (1978). Monopoly and product quality. Journal of Economics Theory 18: 301-317.

NASS (2007). Acreage. Report by the National Agricultural Statistics Service, Washington, D.C.: US Department of Agriculture, June.

Neill, H. R., Cummings, R. G., Ganderton, P. T., Harrison, G. W. and McGuckin, T. (1994). Hypothetical surveys and real economic commitments. Land Economics 70: 145-154.

Noussair, C., Robin, S. and Ruffieux, B. (2004). Do consumers really refuse to buy genetically modified food?” Economic Journal 115: 102-120.

Paarlberg, R. (2008). Starved for Science—How Biotechnology is Being Kept Out of Africa. Cambridge, MA: Harvard University Press.

Pew Initiative (2004). Issues in the Regulation of Genetically Engineered Plants and Animals. Washington, D.C., Pew Initiative on Food and Biotechnology. April.

Pew Initiative (2007). Applications of Biotechnology for Functional Foods. Washington, D.C., Pew Initiative on Food and Biotechnology.

Pray, C., Paarlberg, R. and Unnevehr, L. (2007). Patterns of political response to biofortified varieties of crops produced with different breeding techniques and agronomic traits. AgBioForum 10: 135-143.

Qaim, M. and Zilberman, D. (2003). Yield effects of genetically modified crops in developing countries. Science 299: 900-902.

Rousu, M. C., Huffman, W. E., Shogren, J. F. and Tegene, A. (2007). Effects and value of verifiable information in a controversial market: Evidence from lab auctions of genetically modified food. Economic Inquiry 45: 409-432. 
Sanvido, O., Stark, M., Romeis, J. and Bigler, F. (2006). Ecological Impacts of Genetically Modified Crops: Experiences from Ten Years of Experimental Field Research and Commercial Cultivation. Zurich, Switzerland: Agroscope Reckenholz-Tänikon Research Station ART.

Scholderer, J. (2005). The GM foods debate in Europe: History, regulatory solutions, and consumer response research. Journal of Public Affairs 5: 263-274.

Sobolevsky, A., Moschini, G. and Lapan, H. (2005). Genetically modified crops and product differentiation: Trade and welfare effects in the soybean complex. American Journal of Agricultural Economics 87: 621-644.

Teece, D. J. (1986). Profiting from technological innovation: Implications for integration, collaboration, licensing and public policy. Research Policy 15: 285-305.

UNCTAD (2006). Tracking the Trend Towards Market Concentration: The Case of the Agricultural Input Industry. UNCTAD/DITC/COM/2005/16, United Nations Conference on Trade and Development.

USDA (2007). EU-27 Annual Agricultural Biotechnology Report, GAIN Report Number E47044, Washington, D.C.: USDA Foreign Agricultural Service.

Viscusi, W. K. (1998). Rational Risk Policy. Oxford: Clarendon Press.

Wheeler, M.B. (2007). Agricultural applications for transgenic livestock. Trends in Biotechnology 25: 204-210.

Wright, B.D. and Pardey, P.G. (2006). The evolving rights to intellectual property protection in the agricultural biosciences. International Journal of Technology and Globalisation 2: 12-29.

Zika, E., Papatryfon, I., Wolf, O., Gómez-Barbero, M., Stein, A. J. and Bock, A-K. (2007). Consequences, Opportunities and Challenges of Modern Biotechnology in Europe. European Commission, Joint Research Centre, Institute for Prospective Technological Studies, Report EUR 22728.

Zilberman, D. (2006). The economics of biotechnology regulation. In Just, R. E., Alston, J., and Zilberman, D. (eds), Regulating Agricultural Biotechnology: Economics and Policy. New York: Springer Publishers, 243-261. 
Table 1. Global trends and European strategy: Worldwide adoption of transgenic crops, 1996-2007 (millions of hectares)

\begin{tabular}{lccccccccccccc}
\hline & 1996 & 1997 & 1998 & 1999 & 2000 & 2001 & 2002 & 2003 & 2004 & 2005 & 2006 & 2007 \\
\hline USA & 1.5 & 8.1 & 20.5 & 28.7 & 30.3 & 35.7 & 39.0 & 42.8 & 47.6 & 49.8 & 54.6 & 57.7 \\
Argentina & 0.1 & 1.4 & 4.3 & 6.7 & 10.0 & 11.8 & 13.5 & 13.9 & 16.2 & 17.1 & 18.0 & 19.1 \\
Brazil & $\ldots$ & $\ldots$ & $\ldots$ & $\ldots$ & $\ldots$ & $\ldots$ & $\ldots$ & 3.0 & 5.0 & 9.4 & 11.5 & 15.0 \\
Canada & 0.1 & 1.3 & 2.8 & 4.0 & 3.0 & 3.2 & 3.5 & 4.4 & 5.4 & 5.8 & 6.1 & 7.0 \\
India & $\ldots$ & $\ldots$ & $\ldots$ & $\ldots$ & $\ldots$ & $\ldots$ & $\ldots$ & $\ldots$ & 0.5 & 1.3 & 3.8 & 6.2 \\
China & $\ldots$ & $<0.1$ & $<0.1$ & 0.3 & 0.5 & 1.5 & 2.1 & 2.8 & 3.7 & 3.3 & 3.5 & 3.8 \\
other & $\ldots$ & 0.1 & 0.1 & 0.2 & 0.4 & 0.4 & 0.6 & 0.8 & 2.6 & 3.3 & 4.5 & 5.5 \\
\multicolumn{1}{c}{ EU } & $\ldots$ & $\ldots$ & 0.02 & 0.03 & 0.03 & 0.01 & 0.03 & 0.03 & 0.06 & 0.05 & 0.06 & 0.11 \\
\hline World & $\mathbf{1 . 7}$ & $\mathbf{1 1 . 0}$ & $\mathbf{2 7 . 8}$ & $\mathbf{3 9 . 9}$ & $\mathbf{4 4 . 2}$ & $\mathbf{5 2 . 6}$ & $\mathbf{5 8 . 7}$ & $\mathbf{6 7 . 7}$ & $\mathbf{8 1 . 0}$ & $\mathbf{9 0 . 0}$ & $\mathbf{1 0 2 . 0}$ & $\mathbf{1 1 4 . 3}$ \\
\hline
\end{tabular}

Source: International Service for the Acquisition of Agri-Biotech Applications. EU data are from Gómez-Barbero and Rodríguez-Cerezo (2007) and GMO Compass website. 